\title{
Use of biological fish silage in broilers feed: Effect on growth performance and meat quality
}

${ }^{1}$ José Carmen Ramírez Ramírez ${ }^{*}$, José Inés Ibarra Espain, ${ }^{1}$ Ranferi Gutiérrez Leyva, ${ }^{2}$ José Armando Ulloa and ${ }^{2}$ Petra Rosas Ulloa.

${ }^{1}$ Laboratory of Bromatology and Animal Nutrition, Academic Unit of Veterinary Medicine and Zootechnics, Autonomous University of Nayarit, Compostela, Nayarit, Mexico;

${ }^{2}$ Food Technology Center, Autonomous University of Nayarit, Tepic, Nayarit, Mexico;

*Corresponding author e-mail: ramcara60@gmail.com

Key words: silage, fish by-products, broilers feeding, meat quality.

Publication date 01/02/2016, http://m.elewa.org/Journals/about-japs/

\section{SUMMARY}

This study was conducted to investigate if the nutritional value of fish silage could improve the growth performance, feed utilization, carcass yield and sensory quality of the meat of broilers. An oven-dried fish silage: soybean meal mixture $(1: 1 \mathrm{w} / \mathrm{w})$ was used to prepare four diets with different levels of inclusion $(0 \%, 10 \%, 20 \%$ and $30 \%)$, which were tested in a randomized design for triplicate with 120 broilers in natural conditions of production. The inclusion of fish silage: soybean mixture on diets did not adversely affect the productive parameters of growth, feed intake and feed conversion ratio after 28 experimental days $(P>0.05)$ than those obtained on control diets. No significant effects were observed on carcass yield, chemical composition and sensory quality attributes of broilers meat between different treatments $(P>0.05)$. It is concluded that fish silage could offer a good alternative for fish by-products utilization and that the production process is an economical and environmentally friendly form of processing wastes from local fish markets of Mexico.

\section{INTRODUCTION}

World fisheries and aquaculture production was $158 \mathrm{Mt}$ in 2012 according to FAO statistics. The proportion used for direct human consumption was 136.2 Mt with the remainder (21.8 Mt) destined to non-food uses. About $35 \%$ of world fishmeal production was obtained from fish residues in 2012, which represents an availability of 14.1 Mt of fisheries and aquaculture byproducts (FAO, 2014). The Mexican fisheries and aquaculture production provides $1.75 \mathrm{Mt}$ to global statistics of 2014, occupying the 17 th place in terms of volume in the world fisheries (CONAPESCA, 2014). Fish by-products in many parts of the world are poorly discarded causing serious environmental and economical problems. However, they are also promising sources of compounds which may be used because of their favourable technological or nutritional properties (Kjos et al., 2000). Artisanal fisheries in the
Mexican Pacific provide an important contribution of fish by-products from commercial species such as Bagre panamensis (chihuil sea-catfish), Peprilus snyderi (salema butterfish), Sphyraena ensis (Mexican barracuda), Trachynotus ovatus (pompano), Argyrosomus regius (meagre) and Diplodus vulgaris (black tail bream), which are not used as ingredients in the production of commercial feeds for livestock industry (CONAPESCA, 2014).

Fish silage is a semi-liquid product resulting from the preservation of whole fish or parts by the addition of acids (inorganic or organic) or by bacterial fermentation, adding latter a carbohydrates source along with lactobacilli species to convert sugars into lactic acid (Borghesi et al., 2008; Ramírez-Ramírez et al., 2008). Fish silage had been used as alternative to fishmeal in animal feeds, particularly in situations 
where fishmeal production or preservation by deep freezing is not available or uneconomical (Alwan et al., 1993; Llanes et al., 2008). During the ensilage process, a majority of the proteins are converted to peptides and a portion of which is hydrolyzed to free amino acids, which they can be used as a high nutritional source for feeding different animals (Vidotti et al., 2003; RamírezRamírez, 2009). Additionally, biological fish silage is an important precursor for lactic acid bacteria, which act as probiotics providing health benefits (Yin et al., 2005; García et al., 2007). In order to enhance the economical values of fish byproducts, fish silage has been evaluated in different studies. Hammoumi et al., (1998) performed feeding trials for 21 days with adult broilers $(1300 \pm 100 \mathrm{~g})$ fed on diets with $25 \%$ and $50 \%$ of silage inclusion (by-products of Sardina pilchardus) and showed that there was a similar increase in growth performance. Viscarra-Magaña

\section{MATERIALS AND METHODS}

3.1 Fish silage production: Fish byproducts contained heads, viscera, skin, bones and meat scraps of marine fishes Peprilus snyderi (salema butterfish), Sphyraena ensis (Mexican barracuda), Trachynotus ovatus (pompano), Argyrosomus regius (meagre), Diplodus vulgaris (black tail bream) and estuarine fish Bagre panamensis (chihuil sea-catfish) obtained from market fisheries in the port of San Blas, Nayarit, Mexico. Fish by-products were minced in a food mixer and extruded in a $1 / 4$ horse-power commercial meat grinder through a die with 5-mm diameter holes (Torrey, San Nicolas, Mexico). Subsequently the mixture was added with sugar cane molasses (18\%, wet basis) and Lactobacillus sp. strain B2 (5\%, wet basis) which was cultivated in MRS medium (de Man Rogosa and Sharpe; MRS, Merck, Darmstadt) at $30^{\circ} \mathrm{C}$ for 24 h until to reach a concentration of $1 \times 10^{9} \mathrm{CFU} / \mathrm{ml}$ (starter culture). Later the fermentation was carried out at pilot scale in a reactor of $50 \mathrm{~kg}$ using the methodology designed by RamírezRamírez et al., (2008). To facilitate handling of semi-liquid fish silage obtained, it was mixed with soybean meal in a ratio $1: 1$ and the resulting mixture was oven-dried at $45{ }^{\circ} \mathrm{C}$ for $48 \mathrm{~h}$. The et al., (1999) reported that $15 \%$ of a mixture of fish silage-sorghum (70\%-30\%) might be included in the diet without adverse effect on feed intake, weight gain and feed conversion ratio of broilers. Other research conducted by Kjos et al., (2000) reported that chicks $(36.3 \pm 0.6 \mathrm{~g})$ fed with fish silage diets (by-products of farmed salmon) at levels of 5 and 10\% had a significant greater weight gain and feed intake. Recently, AlMarzooqi et al., (2010) reported that fish silage could replace up to $20 \%$ of soybean meal in broiler diets without affecting growth performance and sensory quality of meat. There are no studies reported in the use of fish silage made of fish by-products like B. panamensis, $P$. snyderi, $S$. ensis, T. ovatus, $A$. regius and $D$. vulgaris carried out with broilers. Therefore, the present study was conducted to investigate the effects of fish silage on growth performance, meat quality and sensory quality of thigh meat.

resulting dried mixture showed a ratio of 1:2.5 (fish silage and soybean meal dry basis) and designed as fish silage soybean meal (FSSM).

3.2 Analyses of fish by-products and fish silage: Fish silage $\mathrm{pH}$ was measured daily during 4 days using a potentiometer UB10 UltraBasic (Denver Instrument, USA). Fish silage samples were diluted in distilled water (1:10) and the lactic acid concentration (\%) was determined by titration with $\mathrm{NaOH} 0.1 \mathrm{~N}$ from a micro burette to give a final $\mathrm{pH}$ of 7.5. The fermentation process was stopped at $\mathrm{pH}$ values of $4.4 \pm 0.02$ and the formation of lactic acid at levels of 4.45 $\pm 0.01 \%$. Microbial analysis of fish silage was determined by colony enumeration of mesophiles, coliforms, lactic acid bacteria, yeast and fungi (Ramírez-Ramírez, 2009). The chemical composition of fish by-products and fish silage: dry matter, crude protein (micro Kjeldahl, $\mathrm{N} \times$ 6.25), crude fat (ether extraction), crude fibre and ash were analyzed according to standard procedures described by the AOAC (2000). Amino acids composition was determined according to the method of Vázquez-Ortiz et al., (1995). 
3.3 Experimental diets: Diets were formulated with FSSM at inclusion levels of $0 \%$ (control), 10\%, 20\% and 30\% (Table 1). Protein content was adjusted in the four diets in order to satisfy the requirements of broilers (NRC, 1994) and control diet contained predominantly soybean meal as protein source. Chemical composition of diets was determined using official methods of AOAC (2000).

Table 1: Composition of experimental diets ( $\mathrm{g} / 100 \mathrm{~g})$.

\begin{tabular}{lllll}
\hline Ingredient & \multicolumn{3}{c}{ Diets } \\
\hline & Control & $10 \%$ & $20 \%$ & $30 \%$ \\
Maize 9\% & 62.18 & 62.18 & 62.18 & 60.77 \\
FSSM $(1: 2.5)$ & 0.00 & 10.00 & 20.00 & 30.00 \\
Soybean meal (44\% of crude protein) & 28.84 & 18.84 & 8.84 & 0.25 \\
Soybean oil & 5.23 & 5.23 & 5.23 & 5.23 \\
Calcium $38 \%$ ) & 1.21 & 1.21 & 1.21 & 1.21 \\
Phosphate 21/17 & 0.77 & 0.77 & 0.77 & 0.77 \\
Pigment 12 g/Kg & 0.46 & 0.46 & 0.46 & 0.46 \\
Salt & 0.42 & 0.42 & 0.42 & 0.42 \\
Methionine 99\% & 0.30 & 0.30 & 0.30 & 0.30 \\
L-Lysine HCL & 0.26 & 0.26 & 0.26 & 0.26 \\
Threonine & 0.13 & 0.13 & 0.13 & 0.13 \\
Cocciodiostat & 0.05 & 0.05 & 0.05 & 0.05 \\
Birds minerals & 0.05 & 0.05 & 0.05 & 0.05 \\
Choline 60\% & 0.05 & 0.05 & 0.05 & 0.05 \\
Vita-Chicken Mix-BM & 0.02 & 0.02 & 0.02 & 0.02 \\
Natuphos Chicken 600 & 0.01 & 0.01 & 0.01 & 0.01 \\
Total & 100 & 100 & 100 & 100 \\
\hline
\end{tabular}

FSSM: Fish silage-soybean meal.

3.4 Feeding and growth trial: Feeding and growth trial was conducted in the experimental farm of the Academic Unit of Veterinary Medicine and Zootechnics, belonging to the Autonomous University of Nayarit (Mexico) with 120 days old Cobb broiler chickens unsexed that were previously fed for 21 days with a commercial feed. To conduct the experiment the birds with a mean initial weight of $576.75 \pm 32.67$ $\mathrm{g}$ were randomly assigned to 12 pens (10 broilers/each treatment) giving three replicates for diets in an opened unit for broilers production. The experimental rearing system was kept under natural spring conditions of photoperiod (cycle of $12.5 \mathrm{~h}$ light/11.5 h dark), relative humidity $(82.9 \pm 8.4 \%)$ and temperature $\left(22.1 \pm 9.5^{\circ} \mathrm{C}\right)$ for 28 days. The animals were remained under hygienic conditions, fed ad libitum (twice a day; 08:00-16:00 h) with feed intake registration, weighed before first feeding at the beginning of the experiment and then every week to record the weight gain.

3.5 Productive, chemical and sensory evaluation of meat: Four broilers from each experimental treatment were chosen randomly and slaughtered at 49 days of age by cervical dislocation and exsanguination. Carcass yield (\%) was calculated with the following equation:

$$
\text { Carcass yield }(\%)=\frac{\text { Carcass weight }}{\text { Final live weight }} \times 100
$$

amples of broilers carcass meat for treatment were pooled and chemical composition was determined using official methods of AOAC (2000). The carcasses were wrapped in plastic bags and immediately frozen. A month after freezing the broilers carcasses were thawed in a microwave oven introduced in closed plastic bags 
and cooked keeping into hot water $\left(80{ }^{\circ} \mathrm{C} / 45\right.$ minutes). For the sensory evaluation, thigh meat was separated and the following parameters were determined: colour, odour, off-odour, flavour, off-flavour, tenderness, juiciness and total quality by an untrained panel of 15 members, using a scale of 1 to 9 , where 1 was the lowest and 9 the highest intensity, for all parameters (Kjos et al., 2000).

3.6 Statistical analysis: Zootechnical parameters of growth trial (feed intake, weight

\section{RESULTS AND DISCUSSION}

4.1 Composition of fish by-products and fish silage: The process of fish by-products had effects on the chemical composition of fish silage (Table 2). The content of protein and lipid decreased in fish silage of $52.41 \%$ to $39.92 \%$ and $24.52 \%$ to $14.54 \%$ respect to fish by-products, respectively. The nitrogen free extract content was higher in the fish silage due to molasses gain and feed conversion ratio), carcass yield, chemical composition and sensory quality attributes of meat were statistically analyzed by one-way ANOVA for a completely randomized design. When significant differences existed among treatments Tukey test for means comparison was used at the 0.05 level of significance (Sokal and Rolhf, 1995). The analyses were processed statistically using NCSS 2007 program (NCSS Inc. USA).

added raising levels of $3.63 \%$ to $26.92 \%$. The addition of Lactobacillus sp. strain B2 to raw material increase lactic acid production and in vitro digestibility of protein at levels of $4.45 \%$ and $81.61 \%$, respectively, respect to fish by-products values $(0.34 \%$ and $69.00 \%)$. Conversely and has expected, $\mathrm{pH}$ descended to 4.43 in reference to fish by-products value (6.49).

Table 2: Chemical composition (\%)*, acidity and in vitro protein digestibility of fish by-products and fish silage.

\begin{tabular}{lcc}
\hline Component & Fish by-products & Fish silage \\
\hline Moisture & $70.34 \pm 0.42$ & $65.54 \pm 0.34$ \\
Crude protein $(\mathrm{Nx} 6.25)$ & $52.41 \pm 0.95$ & $39.92 \pm 0.75$ \\
Ethereal extract & $24.52 \pm 0.61$ & $14.54 \pm 0.44$ \\
Ash & $19.03 \pm 0.53$ & $18.05 \pm 0.63$ \\
Nitrogen free extract & $3.63 \pm 0.24$ & $26.92 \pm 0.61$ \\
pH & $6.49 \pm 0.03$ & $4.43 \pm 0.02$ \\
Lactic acid $(\%)$ & $0.34 \pm 0.01$ & $4.45 \pm 0.01$ \\
Protein digestibility $(\%)$ & $69.00 \pm 1.51$ & $81.61 \pm 0.94$ \\
\hline
\end{tabular}

$*=$ Mean \pm SD values, $(\mathrm{n}=3)$, expressed in dry basis.

The decrease in $\mathrm{pH}$ and high lactic acid production prevented the growth of harmful microorganisms, which allowed the preservation of fish silage. The product showed greyish brown colour, pleasant sweet aroma and faint fish odour, the latter being caused by the residual molasses. In addition, aromatic compounds might be due to proteolytic activity, thus improving sensorial properties. Furthermore, the protein hydrolysis occurring during the fermentation increased the digestibility of fish silage $(69 \%$ to $81.61 \%)$; therefore it is more convenient in diets formulation. This could be due to the release of peptides and free amino acids from protein hydrolyzed which could have potential chemo-attractants as well as feeding stimulants in carnivorous and in other animal species (Lian et al., 2005). The fish silage obtained showed similar concentrations of histidine, threonine, methionine, valine and isoleucine that fishmeal with the exception of glycine and tyrosine (Table 3). 
Table 3: Amino acid content ( $\mathrm{g} / 100 \mathrm{~g}$ protein)* in fish silage and fishmeal.

\begin{tabular}{lll} 
Amino acid & Fish silage & Fishmeal \\
\hline Aspartic acid & 3.13 & 5.84 \\
Glutamic acid & 4.45 & 8.72 \\
Serine & 1.72 & 2.93 \\
Histidine & 1.84 & 1.32 \\
Glycine & 7.71 & 5.21 \\
Threonine & 2.42 & 2.84 \\
Arginine & 1.94 & 5.73 \\
Alanine & 5.22 & 4.46 \\
Tyrosine & 4.32 & 2.04 \\
Methionine & 2.05 & 1.75 \\
Valine & 2.54 & 2.93 \\
Phenylalanine & 1.72 & 2.54 \\
Isoleucine & 2.41 & 2.63 \\
Leucine & 3.24 & 4.52 \\
Lysine & 2.23 & 3.91 \\
\hline
\end{tabular}

$*=$ Mean values $(\mathrm{n}=3)$.

The content of histidine, threonine, methionine, glycine, alanine and tyrosine in fish silage was higher than fermented silage of silver hake reported (White et al., 1999). In contrast, Dong et al., (1993) reported higher amino acid content in fermented silage of salmon viscera, except for glycine and tyrosine compared with our results. Moreover, most of the amino acids content was close to half of that reported for fermented silage from tilapia wastes (Vidotti et al., 2003). However, the same authors reported two fold more aspartic and glutamic acid, and lower tyrosine than fish silage obtained in this study. Likewise, higher amino acids content of biological fish silage from surimi processing wastes (Zynudheen et al., 2008) and chemical silage of whole Spanish mackerel (SantanaDelgado et al., 2008) were reported in comparison with our results.

\subsection{Composition of experimental diets:}

The chemical composition of the experimental diets is presented in table 4 . The average moisture content of the four diets was $4.41 \%$, and the inclusion of $30 \%$ in the diet of FSSM caused a decrease showing the lower value. The mineral content was higher by increasing the FSSM in the diet, which is due to fish by-products used in FSSM production as important source of these nutrients. The percentage of crude protein was similar in the four diets with an average of 20.55 $\pm 0.74 \%$, which covered the requirements of this nutrient in broilers. The crude fat content was higher in diets with more fish silage: soybean meal mixture, which was mainly due to the oil of fish silage, possibly being an important source of omega-3 fatty acids (Rustad et al., 2011). The crude fibre content in the four experimental diets was low with an average of $2.58 \pm 0.62 \%$, however, this meets the minimum requirement needed for broilers (NRC, 1994). 
Table 4: Chemical analysis* of experimental diets added with fish silage: soybean meal mixture used in feeding trial of broilers.

\begin{tabular}{|c|c|c|c|c|}
\hline \multirow[t]{2}{*}{ Component (g/100 g) } & \multicolumn{4}{|c|}{ FSSM level in diet } \\
\hline & Control & $10 \%$ & $20 \%$ & $30 \%$ \\
\hline Moisture & $4.53 \pm 0.33$ & $5.14 \pm 0.42$ & $5.54 \pm 0.13$ & $2.44 \pm 0.13$ \\
\hline Crude protein (Nx6.25) & $20.02 \pm 0.31$ & $21.43 \pm 0.71$ & $19.82 \pm 0.84$ & $20.15 \pm 2.13$ \\
\hline Ethereal extract & $7.14 \pm 1.24$ & $11.52 \pm 1.53$ & $9.21 \pm 2.13$ & $12.8 \pm 1.82$ \\
\hline Crude fibre & $3.25 \pm 0.23$ & $2.31 \pm 0.34$ & $1.84 \pm 0.11$ & $2.4 \pm 0.71$ \\
\hline Ash & $3.53 \pm 0.22$ & $4.65 \pm 0.21$ & $5.35 \pm 0.32$ & $6.2 \pm 0.34$ \\
\hline Nitrogen free extract & $61.82 \pm 1.03$ & $54.53 \pm 1.12$ & $58.45 \pm 1.62$ & $55.3 \pm 1.05$ \\
\hline
\end{tabular}

FSSM: Fish silage: soybean meal

$*=$ Values (means $\pm \mathrm{SD}, \mathrm{n}=3$ ) expressed in wet basis.

4.3 Feed intake and feed conversion ratio:

Broilers feed intake had no significant difference between treatments during every weeks $(P>0.05)$, resulting the lowest value at first 7 days with an average value of $717.46 \mathrm{~g} /$ chicken and higher feed intake was between 14 and 21 days with
$1034.35 \mathrm{~g} /$ chicken (Figure 1). These results agree with those reported by Espe et al., (1992) who included up to $30 \%$ of herring offal silage in broilers diet and significant effect on feed intake was not found.

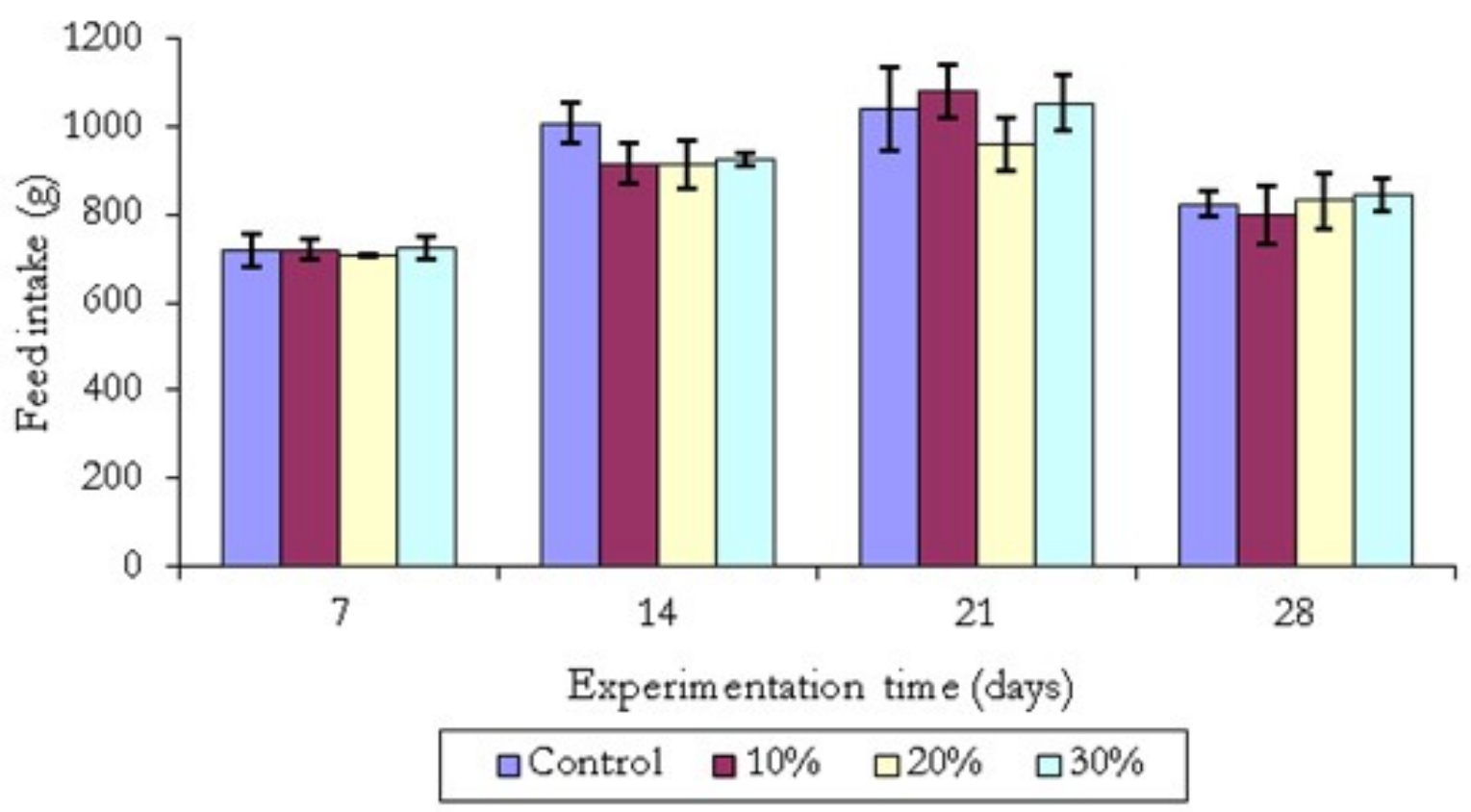

Figure 1: Feed intake of broilers fed on diets containing different levels of FSSM.

Santana-Delgado et al., (2008) demonstrated that the inclusion of $0 \%, 11 \%$ and $22 \%$ of dried fish silage: sorghum mixture in broiler diets did not affect feed intake, which are similar to this study findings. However, other studies showed higher feed intake in broilers by including fish silage in the diet (Kjos et al., 2000; Betancourt et al., 2005). The contrasting results might be associated with various factors that modulate feed intake in birds such as genetic variation between strain, 
environmental temperature, energetic content of the diet, texture and palatability of the feed, among others (Abdullah et al., 2010; Siegel, 2014). The feed conversion ratio of control diet (2.49) at 14 days of experimentation showed significant difference $(P<0.05)$ than the other three treatments added with FSSM and represents a positive aspect in the feed utilization of diets with different levels of FSSM (Table 5).

Table 5: Feed conversion ratio (g feed/g gain) ${ }^{*}$ of broilers fed on diets containing different levels of FSSM.

\begin{tabular}{ccccc}
\hline Diet & \multicolumn{4}{c}{ Experimental time (days) } \\
\cline { 2 - 5 } & $\mathbf{7}$ & $\mathbf{1 4}$ & $\mathbf{2 1}$ & $\mathbf{2 8}$ \\
\hline Control & $1.99 \pm 0.51^{\mathrm{a}}$ & $2.49 \pm 0.46^{\mathrm{b}}$ & $1.94 \pm 0.21^{\mathrm{a}}$ & $2.33 \pm 0.22^{\mathrm{a}}$ \\
$10 \%$ & $1.37 \pm 0.25^{\mathrm{a}}$ & $1.93 \pm 0.08^{\mathrm{a}}$ & $1.90 \pm 0.19^{\mathrm{a}}$ & $2.09 \pm 0.04^{\mathrm{a}}$ \\
$20 \%$ & $1.65 \pm 0.12^{\mathrm{a}}$ & $1.91 \pm 0.12^{\mathrm{a}}$ & $1.68 \pm 0.04^{\mathrm{a}}$ & $2.04 \pm 0.12^{\mathrm{a}}$ \\
$30 \%$ & $1.86 \pm 0.13^{\mathrm{a}}$ & $1.88 \pm 0.19^{\mathrm{a}}$ & $1.77 \pm 0.10^{\mathrm{a}}$ & $2.29 \pm 0.15^{\mathrm{a}}$ \\
\hline
\end{tabular}

FSSM: fish silage: soybean meal.

$*_{\mathrm{n}}=3$; data from three replicates of 10 birds each per treatment group.

a-b: Different letters in a column indicate significant differences among treatments $(P<0.05)$.

The foregoing shows that during this growth period (14 days) fish silage inclusion in diet improved feed conversion in broilers, which may be due to hydrolyzed protein and the supply of essential amino acids such as histidine, threonine, methionine, valine and isoleucine present in fish silage (Table 3). At 21 and 28 days of the study, feed conversion between experimental groups was not statistically different $(P>0.05$; Table 5$)$. These study findings are consistent with other reports in which fish silage at different levels of inclusion in diets for broilers did not affect feed conversion (Espe et al., 1992; Vizcarra-Magaña et al., 1999; Betancourt et al., 2005; Santana-Delgado et al., 2008; Al-Marzooqy et al., 2010). The feed conversion values obtained at 7 and 14 days of experimentation (28 and 35 days old chickens, respectively) agrees with that reported by $\mathrm{Al}$ Marzooqy et al., (2010) who included up to $30 \%$ of fish silage in broilers diet. However Kjos et al., (2000) reported significantly better-feed conversion values in broilers by including fish silage and fish oil in the feed. The differences found in the feed utilization suggest that the raw material sources used to produce fish silage, age of animals, bioassay conditions, among other factors, can have an impact on broilers performance. Nevertheless, the fish silage: soybean mixture can be an important economical alternative to broiler feeding, all this as a function of global demand and prices increases for fishmeal proposal for the coming years (Hardy, 2010).

4.4 Growth performance: Chickens showed great feed intake, which was reflected in a rapid increase in weight from the beginning of the experiment (Figure 2). Body weight of chickens weekly did not show significant difference between treatments $(P>0.05)$, although the chicks in treatments with fish silage-soybean meal mixture exhibited a slightly higher weight gain than the control. 


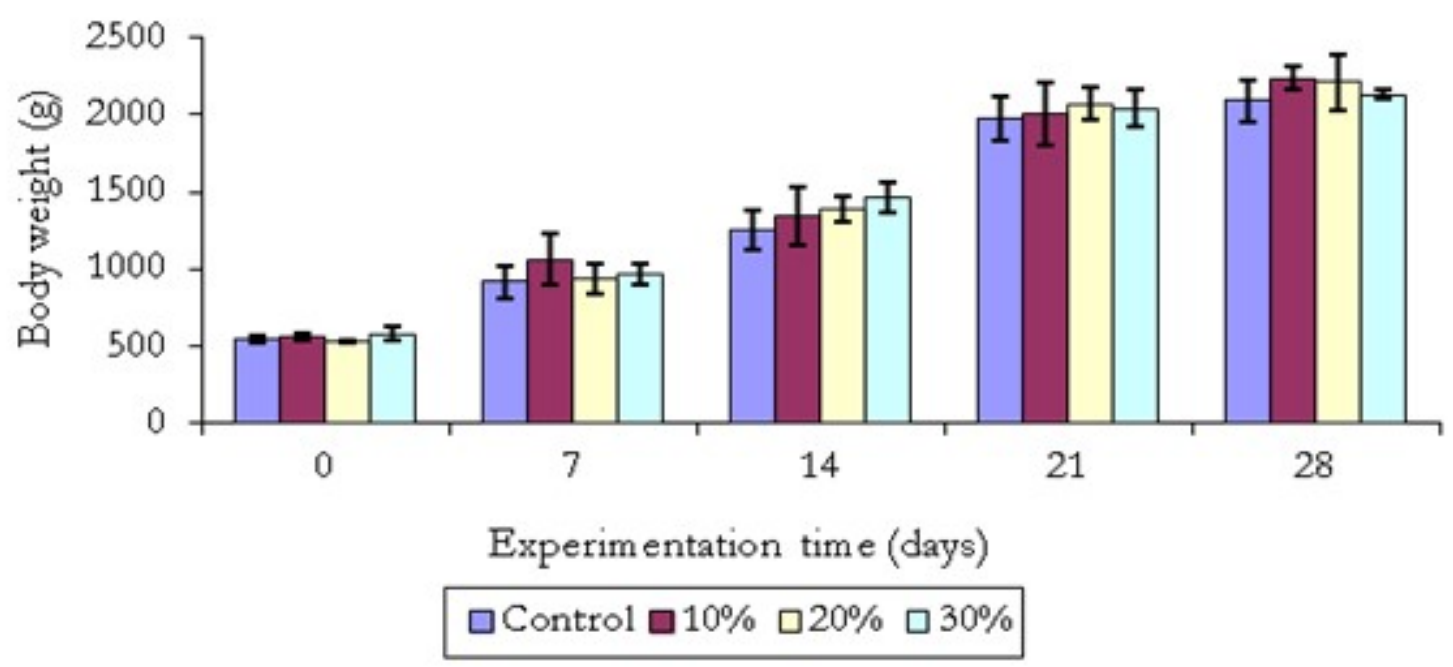

Figure 2: Growth response of broilers fed with diets containing different levels of FSSM.

Other authors reported that the inclusion of fish silage in the diet showed no effect on weight gain in broilers, which agrees with this study results (Espe et al., 1992; Vizcarra-Magaña et al., 1999; Santana-Delgado et al., 2008; Al-Marzooqy et al., 2010). However, Kjos et al. (2000) found better weight gain in broilers by including fish silage $(5 \%)$ and fish oil $(0.8 \%)$ in the diet. Also, Betancourt et al., (2005) reported a significant effect $(P<0.05)$ of slaughter weight $(2.25 \mathrm{Kg})$ in chickens fed with a diet that included $20 \%$ of trout viscera silage compared with the results of diets with inclusion levels of $0 \%$ and $10 \%$.

\subsection{Analysis and sensory evaluation of} meat: The inclusion of FSSM on diets did not affect significantly carcass yield of broilers and resulted in an average of $68.25 \%(P>0.05)$. Similar results were obtained in broilers when replaced up to 75 or $100 \%$ of protein provided by soybean meal with tilapia by-products meal (Maigualema and Gernat, 2003). However, recently Ramírez-Ramírez et al., (2013) demonstrated that fish silage level in quails feed did not affect carcass yield (70.3\%), which was higher than in this work and therefore, indicating that different species of birds apparently used nutrients and energy from fish silage efficiently. The chemical composition of chicken thigh meat is shown in Table 6. The contents of moisture, crude protein and ash showed no significant difference between treatments $(P>0.05)$ with average values of $74.25 \%, 20.80 \%$ and $0.96 \%$, respectively. However, the inclusion of FSSM had a positive effect of increase the fat content of meat compared to the control treatment $(P<0.05)$, this is related to the oil content of the diets and could be an important source of omega3 fatty acids in broiler meat that must be studied in depth. 
Table 6: Effect of diets with different levels of FSSM on chemical composition of broilers meat in dry basis.

\begin{tabular}{lcrrr}
\hline Ingredient (g/100g) & \multicolumn{4}{c}{ FSSM level in diet } \\
\hline Moisture & Control & \multicolumn{1}{c}{$\mathbf{1 0 \%}$} & $\mathbf{2 0 \%}$ & \multicolumn{1}{c}{$\mathbf{3 0 \%}$} \\
Crude protein (Nx6.25) & $74.32 \pm 1.35 \mathrm{a}$ & $73.44 \pm 1.65 \mathrm{a}$ & $73.84 \pm 0.95 \mathrm{a}$ & $75.60 \pm 1.65 \mathrm{a}$ \\
Ethereal extract & $20.26 \pm 0.76 \mathrm{a}$ & $20.86 \pm 0.48 \mathrm{a}$ & $20.39 \pm 1.25 \mathrm{a}$ & $21.70 \pm 0.17 \mathrm{a}$ \\
Ash & $2.90 \pm 0.04 \mathrm{a}$ & $3.69 \pm 0.17 \mathrm{~b}$ & $3.39 \pm 0.05 \mathrm{~b}$ & $3.37 \pm 0.31 \mathrm{~b}$ \\
& $0.98 \pm 0.10 \mathrm{a}$ & $0.98 \pm 0.05 \mathrm{a}$ & $0.89 \pm 0.05 \mathrm{a}$ & $1.01 \pm 0.09 \mathrm{a}$ \\
\hline
\end{tabular}

FSSM: fish silage: soybean meal

a-b: Different letters in each row indicate significant differences among treatments $(P<0.05)$.

Chicken thigh meat attributes were not affected significantly by the addition of FSSM on the diet $(P>0.05)$, this apparently indicates that under the conditions of this study, the meat was properly accepted by the untrained panellists (Table 7). Contrary to this study, Krogdahl (1985) reported that fish silage oil in feed $(1.5 \%)$ adversely affected the sensory quality of chicken meat (leg and breast) and caused rejection by the judges. On the other hand, Lopez-Ferrer et al., (1999) reported that the addition of fish oil in chicken food $(8.2 \%)$ produced an unacceptable taste of the meat. Moreover, fish silage $(5 \%)$ and fish oil (1.7 to $2.5 \%$ ) added in broiler chickens feed, caused odour and taste of fish in the leg meat (Kjos et al., 2000). The same authors reported lower juiciness and tenderness intensity of chicken meat than those obtained in this study. It has been also reported that the addition of fishmeal together with fish silage in the broiler diet $(4.0 \%$ each) produced strong fish odour and flavour in the meat (Mielnik et al., 2002). Moreover, recently Al-Marzooqy et al., (2010) reported that the addition (30\%) of fish silage: corn mixture (8.5:1.5 ratio) in the diets supplied to the birds caused an off flavour in chicken breast meat, which was described as "fishy" by the sensory panel. In this regard, present findings could be very valuable because the addition of FSSM up to $30 \%$ in the feed did not alter the sensory quality of broiler meat.

Table 7: Effect of diets with different levels of FSSM on the sensory quality of broilers thigh meat.

\begin{tabular}{l|l|l|l|l|l|l}
\hline Diet & \multicolumn{5}{|c}{ Sensory quality attribute* } \\
& Colour & Odour & Flavour & Tenderness & Juiciness & $\begin{array}{l}\text { Total } \\
\text { quality }\end{array}$ \\
& & & & & & \\
\hline Control & $5.44 \pm 2.29$ & $6.13 \pm 1.99$ & $5.93 \pm 2.34$ & $6.53 \pm 1.76$ & $6.66 \pm 2.25$ & $5.66 \pm 3.01$ \\
$10 \%$ & $6.07 \pm 2.50$ & $5.73 \pm 2.37$ & $6.46 \pm 2.77$ & $7.46 \pm 1.55$ & $7.33 \pm 1.63$ & $6.23 \pm 2.63$ \\
$20 \%$ & $6.63 \pm 2.13$ & $6.23 \pm 2.51$ & $6.8 \pm 2.17$ & $7.46 \pm 1.40$ & $6.6 \pm 1.99$ & $7.06 \pm 1.45$ \\
$30 \%$ & $6.13 \pm 2.23$ & $6.62 \pm 2.35$ & $6.46 \pm 1.84$ & $7.13 \pm 1.88$ & $7.13 \pm 1.72$ & $6.73 \pm 1.62$ \\
\hline
\end{tabular}

FSSM: fish silage: soybean meal

${ }^{*}$ Mean values of panellists answers $(n=15)$.

Scale of 1 to 9 , where 1 was the lowest and 9 the highest intensity for each sensory quality attribute.

\section{CONCLUSION}

The present study demonstrated the feasibility of using the combination of different fish byproducts as biological silage in broiler feed, because, the inclusion of fish silage: soybean mixture (FSSM) on diets not adversely affects the productive parameters, carcass yield and sensory quality of the meat. The fish silage produced by lactic acid fermentation is an easy and attractive 
biotechnological process to utilize fish byproducts, and could provide a reliable and

\section{ACKNOWLEDGEMENTS}

The authors thank "Production Units and Poultry Farm" of the Academic Unit of Veterinary Medicine and Zootechnics, belonging to the Autonomous University of Nayarit, for providing

\section{REFERENCES}

Abdullah A, Al-Beitawi N, Rjoup M, Qudsieh R. and Ishmais M: 2010. Growth performance, carcass and meat quality characteristics of different commercial crosses of broilers strains of chickens. The Journal of Poultry Science. 47(1):1321.

Al-Marzooqi W, Al-Farsi MA, Kadim IT, Mahgoub O. and Goddard JS: 2010. The effect of feeding different levels of sardine fish silage on broiler performance, meat quality and sensory characteristics under closed and opensided housing systems. Asian-Australasin Journal of Animal Sciences. 23:16141625.

AOAC (Association of Official Analytical Chemists): 2000. Official Methods of Analysis of the Association of Official. 17th Edition. Washington, D.C. 20044, USA. 1018 p.

Betancourt L, Díaz GJ, Aguilar X. and Ríos J: 2005. Effect of ensiled trout (Oncorbynchus mykiss) intestines on productive traits of broiler chickens and the content of omega-3 fatty acids in liver, thighs and breast. Livestock Research for Rural Development. 17(9). Available from: http://www.lrrd.org/lrrd17/9/beta17106 .htm.

Alwan S.R., Buckley D.J. and O'Connor T.P: 1993. Silage from fish wastes: Chemical and microbiological aspects. Irish Journal of Agricultural and Food Research. 32:75-81.

Borghesi R, Portz L, Oetterer M. and Zyrino JEP: 2008. Apparent digestibility sustainable form of processing fish by-products from local fish markets of Mexico.

facilities to carry out this work. The technical assistance of MVZ Francisco Arce Romero is greatly appreciated.

coefficient of protein and amino acids of acid, biological and enzymatic silage for Nile tilapia (Oreochromis Niloticus). Aquaculture Nutrition. 14:242-248.

CONAPESCA: 2014. National Commission of Aquaculture and Fishing. Statistical Yearbook of Aquaculture and Fisheries 2014. Accesed 5/07/2015. Mexico, available from URL: http:// www.conapesca.sagarpa.gob.mx/wb/con a/cona anuario estadistico de pesca

Dong FM, Fairgrieve DI, Skonberg DI. and Rasco BA: 1993. Preparation and nutrient analyses of lactic acid bacterial ensiled salmon viscera. Aquaculture. 109:351366.

Espe M, Haaland H. and Njaa LR: 1992. Substitution of fish silage protein and a free amino acid mixture for fish meal protein in a chicken diet. Journal of the Science Food and Agriculture. 58:315319.

FAO: 2014. The State of World Fisheries and Aquaculture 2104. Opportunities and challenges. Accesed 14/06/2015. Roma, Italia, available from URL: $\quad$ http://www.fao.org/3/ai3720e.pdf

García Y, Boucourt R, Acosta A, Albelo N. and Núñez O: 2007. Effect of a probiotic mixture of Lactobacillus acidophilus and Lactobacillus rhamnosus on some health and physiological indicators in broilers in the tropics. Cuban Journal Agriculture Science. 41:69-72.

Hammoumi A, Faid M. and Amarouch H: 1998. Characterization of fermented fish waste used in feeding trials with 
broilers. Process Biochemistry. 33:423427.

Hardy RW: 2010. Utilization of plant proteins in fish diets: effects of global demand and supplies of fishmeal. Aquaculture Research. 41:770-776.

Kjos NP, Herstad O, Øverlad M. and Skrede A: 2000. Effects of dietary fish silage and fish fat on growth performance and meat quality of broiler chicks. Canadian Journal of Animal Science. 80:625-632.

Krogdahl $\AA$ : 1985 . Fish viscera silage as a protein source for poultry. 2. Experiments with meat-type chickens and ducks. Acta Agriculturae Scandinavica. 35:24-32.

Lian PZ, Lee CM. and Park E: 2005. Characterization of squid-processing byproduct hydrolysate and its potential as aquaculture feed ingredient. Journal of Agricultural and Food Chemistry. 53:5587-5592.

Llanes J, Toledo J. and Lazo de la Vega J: 2008. Performance of African catfish (Claria gariepinus) fed a semi-humid diet, based on biological fish silage. Cuban Journal of Agricultural Science. 42:263-266.

Lopez-Ferrer S, Baucells MD, Barroeta AC. and Grashorn MA: 1999. n-3 enrichment of chicken meat using fish oil: Alternative substitution with rapeseed and linseed oils. Poultry Science. 78:356-365.

Maigualema MA. and Gernat AG: 2003. The effect of feeding elevated levels of tilapia (Oreochromus niloticus) by-product meal on broiler performance and carcass characteristics. International Journal of Poultry Science. 2:195-199.

Mielnik M, Herstad O, Lea P, Nordal J. and Nilsson A: 2002. Sensory quality of marinated frozen stored chicken thighs as affected by dietary fish fat and vitamin E. International Journal of Food Science \& Technology. 37:29-39.

NRC: 1994. National Research Council. Nutrient requirements of poultry. 9th Edition. Washington, D.C.

Ramírez-Ramírez JC, Huerta S, Arias L, Prado A. and Shirai K: 2008. Utilization of shrimp by-catch and fish wastes by lactic acid fermentation and evaluation of degree of protein hydrolysis and in vitro digestibility. Revista Mexicana de Ingeniería Química. 7: 195-204.

Ramírez-Ramírez JC: 2009. Utilization of shrimp by catch and fishery by-products through fish silage production. PhD. Thesis. Autonomous Metropolitan University, Mexico City.

Ramírez-Ramírez JC, Ibarra JI, Arce F, Rosas P, Ulloa JA, Shirai K, Vallejo B. and Mazorra MA: 2013. Preparation of biological fish silage and its effect on the performance and meat quality characteristics of quails (Coturnix coturnix japonica). Brazilian Archives of Biology and Technology. 56:1002-1010.

Rustad T, Storrø I. and Slizyte R: 2011. Possibilities for the utilization of marine by-products. International Journal of Food Science \& Technology. 46:20012014.

Santana-Delgado H, Avila E. and Sotelo A: 2008. Preparation of fish silage of Spanish mackerel (Scomberomorus maculates) and its evaluation in broiler diets. Animal Feed Science and Technology. 141:129-140.

Siegel P: 2014. Evolution of the modern broiler and feed efficiency. Annual Review of Animal Biosciences 2:375-385.

Sokal R. and Rohlf F: 1995. Biometry: the principles and practice of statistics in biological research. 3rd edn. WH Freeman. New York, USA. pp. 887.

Vázquez-Ortiz FA, Caire G, Higuera-Ciapara I. and Hernández G: 1995. High performance liquid chromatographic determination of free amino acids in shrimp. Journal of Liquid Chromatography \& Related Technologies. 18:2059-2068.

Vidotti RM, Macedo EM. and Carneiro DJ: 2003. Amino acid composition of processed fish silage using different raw materials. Animal Feed Science and Technology. 105:199-204. 
Vizcarra-Magaña L, Avila E. and Sotelo A: 1999. Silage preparation from tuna fish wastes and its nutritional evaluation in broilers. Journal of the Science of Food and Agriculture. 79:1915-1922.

White MB., Anderson DM. and Rouvinen KI: 1999. Apparent digestibility coefficients of raw ground, acid and fermented silver hake (Merluccius bilinearis) feedstuffs for mink and evaluation of the storage stability of the silages. Canadian Journal of Animal Science. 79:375-381.

Yin LJ, Tong YL. and Jiang ST: 2005. Improvement of the functionality of minced mackerel by hydrolysis and subsequent lactic acid bacterial fermentation. Journal of Food Science. 70:172-178.

Zynudheen AA, Anandan R. and Ramachandran Nair KG: 2008. Effect of dietary supplementation of fermented fish silage on egg production in Japanese quail (Coturnix coromandelica). African Journal of Agricultural Research. 3:379-383. 